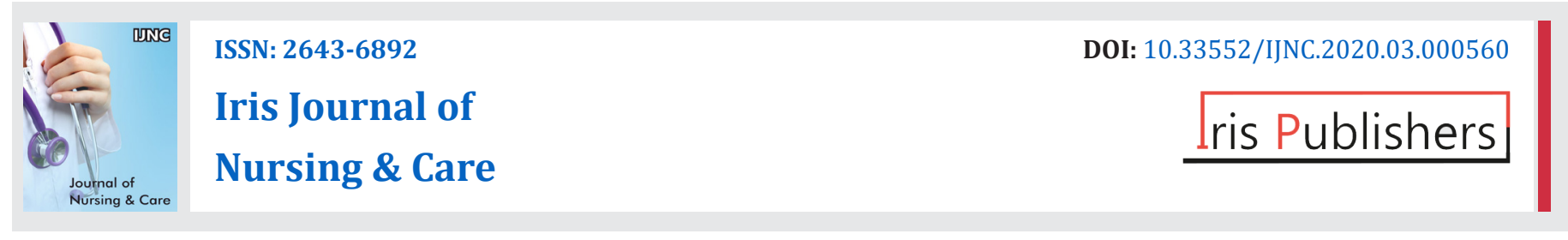

Mini Review

Copyright (C) All rights are reserved by Jennifer Marie Litchfield

\title{
Creating a Sustainable Clinical Adjunct Faculty Mentorship Program
}

\author{
Jennifer Marie Litchfield*1, Donna White ${ }^{2}$ and Maureen Allen ${ }^{3}$ \\ Nurse Administrator-Pre-Licensure and Post-Licensure Nursing Programs, Becker College, USA \\ Clinical Liaison, Pre-Licensure Nursing Programs, Becker College, USA \\ Director Post-Licensure Nursing Programs, Becker College, USA
}

*Corresponding author: Jennifer Marie Litchfield, Nurse Administrator-PreLicensure and Post-Licensure Nursing Programs, Becker College, USA.

Received Date: July 08, 2020

Published Date: July 23, 2020

\section{Abstract}

Background: A mentoring program supports people to manage their own learning needs so that they may maximize their potential in the clinical setting. The mentorship program paired newly hired clinical faculty, waivered faculty, and/or clinical faculty who request it, with senior colleagues in the nursing program. The mentor/mentee pair met throughout the academic year to work toward goals that they develop together and are required in the job description for clinical adjunct instructors. Monthly meetings were required. A final summary meeting occurred face to face. The mentor completed a progress note during each meeting with a final summary note sheet completed at the end of the mentoring period. Offering stipends to full-time faculty assists with faculty engagement. Mentoring is a powerful tool that helps new clinical faculty achieve personal and professional goals.

Questions: What supports/resources are needed for new adjunct clinical faculty? Will full-time faculty participate in a mentorship program? What are the responsibilities of the mentor/mentee? How are mentees prepared for the role? How are mentors prepared for the role? How do mentors and faculty assess the progress and satisfaction of new faculty members?

Issues: The National League for Nursing (NLN) Board of Governors published a position statement, Mentoring of Nurse Faculty, in 2006. The statement encourages the thoughtful use of mentoring as a resource to foster the career development of faculty, develop the enrollment and retention of nurse educators, and create a positive work environment [1].

Purpose: The purpose is to explore the needs for newly hired adjunct clinical faculty. The nursing program must meet regulatory requirements of the Board of Registration in Nursing regarding newly hired and waivered nursing faculty.

Themes: Engagement, nursing faculty shortage, and workload.

\section{Introduction}

"Mentoring of new faculty by nurses experienced in the faculty role is the single most influential way to bring our new cohorts into the circle of academia, thereby preventing the isolation, frustration, and dissatisfaction commonly seen in new nursing faculty. Mentoring assists our new peers, as well as their mentors, in the growth and maturation of their professional selves [2]."

\section{Engagement}

Mentoring requires a partnership between the mentor and mentee. In order for the mentorship to be successful, likenesses

should occur. Couplings of mentor/ mentee must be grounded on personality, philosophical beliefs, and clinical teaching areas [2]. The Nurse of the Future will purpose efficiently within nursing and interdisciplinary teams, developing open communication, shared respect, collective decision making, learning, and development [3].

\section{Teamwork and Collaboration}

Self: (Table 1)

Team communication: (Table 2 ) 
Table 1

\begin{tabular}{|c|c|c|}
\hline Knowledge & Attitudes/Behaviors & Skills \\
\hline $\begin{array}{c}\text { K1 Identifies own strengths, } \\
\text { limitations, and values in functioning } \\
\text { as a member of a team }\end{array}$ & $\begin{array}{c}\text { A1a Recognizes responsibility for contributing to } \\
\text { effective team functioning }\end{array}$ & $\begin{array}{c}\text { S1a Acts with honesty and integrity when } \\
\text { working with patients, families, and team members }\end{array}$ \\
\hline & A1b Appreciates the importance of collaboration & $\begin{array}{c}\text { S1b Demonstrates self-awareness of strengths } \\
\text { and limitations as a team member }\end{array}$ \\
\hline & $\begin{array}{c}\text { A1c Recognizes the value of mutual respect and } \\
\text { collegial trust among team members }\end{array}$ & $\begin{array}{c}\text { S1c Initiates plan for self-development as a team } \\
\text { member }\end{array}$ \\
\hline & $\begin{array}{c}\text { S1d Acts collaboratively with integrity, } \\
\text { views }\end{array}$ \\
\hline
\end{tabular}

Table 2

\begin{tabular}{|c|c|c|}
\hline \multicolumn{1}{|c|}{ Knowledge } & Attitudes/Behaviors & Skills \\
\hline $\begin{array}{c}\text { K5 Understands the impact of the effective } \\
\text { collegial communication on patient outcomes }\end{array}$ & $\begin{array}{c}\text { A5 Values teamwork and the } \\
\text { relationships upon which it is based }\end{array}$ & $\begin{array}{c}\text { S5a Adapts own communication style to meet } \\
\text { the needs of the patient, family, team and situation }\end{array}$ \\
\hline & & S5b Demonstrates commitment to team goals \\
\hline & & $\begin{array}{c}\text { S5c Solicits input from other team members to } \\
\text { improve individual and team performance }\end{array}$ \\
\hline & $\begin{array}{c}\text { S5d Shares instructive feedback on } \\
\text { performance in respectful ways }\end{array}$ \\
\hline
\end{tabular}

\section{Nursing Faculty Shortage}

The average age of faculty members is increasing. According to the American Association of Colleges of Nursing, "the average ages of doctorally-prepared nurse faculty holding the ranks of professor, associate professor, and assistant professor were 61.6, 57.6, and 51.4 years, respectively. For master's degree-prepared nurse faculty, the average ages for professors, associate professors, and assistant professors were 57.1, 56.8, and 51.2 years, respectively [4,5]."

\section{Workload}

Newly hired faculty must be oriented within the school to fully understand the nursing department. Offering new faculty (mentees) reduced workloads during the first year and decreasing workloads for mentors facilitates an extensive orientation.

\section{Conclusion}

The mentorship program pairs newly hired clinical faculty, waivered faculty, and/or clinical faculty who request it, with senior colleagues in the nursing program at Becker College. Mentoring is a powerful tool that helps new clinical faculty achieve personal and professional goals.

\section{Acknowledgement}

We would like to thank the nursing staff, nursing faculty, and college-wide administration at Becker College for their support and guidance.

\section{Conflict of Interest}

Author declare no conflict of interest.

\section{References}

1. National League for Nursing (2006) Position statement: Mentoring nurse faculty.

2. Dunham Taylor, Lynn, Moore, McDaniel and Walker (2008) What goes around comes around: Improving faculty retention through more effective mentoring. Journal of Professional Nursing 24(6): 337-346.

3. Quality and Safety Education for Nurses (2017) QSEN competencies.

4. American Association of Critical Care Nursing (2015).

5. Benner P (1984) From novice to expert: Excellence and power in clinical nursing practice. Menlo Park: Addison-Wesley. 